\title{
Lifting the Veil off the Intimate in Jordanian Women's Literature
}

\author{
By Omnia Amin *
}

The contemporary scene in Jordanian women's literature offers an intense intellectual debate that is emerging in a fundamentally new way of thinking about women in a modern globalized world. Theirs is a novel voice of gender politics that calls for progress, emaciation and empowerment of women. They do not seek merely to deconstruct the myth of the superior masculine ego that still continues to shape the socio-political fabric of Jordanian society, but they seek a more globalized perspective to detangle themselves by giving birth to a new consciousness. By lifting the veil off their personal and intimate experiences they give rise to a more global oriented image and join modern feminist writers in their endeavor to expose a world of political, economic and social system built on power rather than on justice. Their writings present a collective voice meant to force public opinion out of polemics about cultural authenticity that insists on subjugating the female body and mind by coercing social taboos created by long outstanding social and political patriarchal based ideologies. They do so by projecting a threatening image of female sexuality and by making the body a site for the intervention and production of discourses about the self and 'other'. They strive to produce an unveiled body and an unveiled discourse showing that the personal is the political and by taking it one step further to assert that the personal affords a global and universal experience.

\section{Introduction}

...the body is not an object to be studied in relation to culture, but is to be considered as the subject of culture, or in other words as the existential ground of culture. (Csordas 1990)

This statement by anthropologist Thomas Csordas is exemplified in the act of writing among female Jordanian writers who present their world as mapped out by the bodies they carry. In turn, the body comes to shape their social and political existence. It also becomes their geographical map that defines their borders, and consequently inhibits their space and restricts their movement. Thus women's writing yields a special insight into the social and cultural set up in the second half of the twentieth century Jordanian society. This paper

${ }^{*}$ Full Professor, Zayed University, Dubai, UAE. 
discusses works of shorter fiction aiming to place the literary texts center stage to reveal significant patterns and themes in the literary culture in Jordan.

The works presented are by prominent female writers writing from the 1970 's onwards as before that time the literary scene in Jordan was predominantly masculine with the exception of a few names. There are mainly two generations of female writers in contemporary Jordanian literature. Leila Elatrash and Samiha Khreis are chosen as examples to represent the first generation of modern women's writings from the 70's onwards. The rest are voices that became prominent in the late 80 's and early 90's and are seen as the younger generation of writers. I have selected Samia Atout and Jawaher Rafaiaa as examples from that period.

Though the history of writing in Jordan is not but a century old, Jordanian female writers have had the advantage of writing from a vantage point as they write with a consciousness about the act of writing itself. Having the western heritage of the feminist movement and feminist theory and criticism behind them, they capitalize on earlier works especially by western writers who paved the way to create a mass consciousness about the act to write and read a text. Their choice to focus on the female body is deliberate, as they aim to change the mass consciousness in their own environment by depicting the injustice done to women and the confinement they suffer from as a result of their gender. The female body has always been a taboo, not from the point of view of regarding the woman as a sacred being, but because women are regarded as subordinate citizens who must remain in the domestic sphere and in subjugation to the men in the family or else they jeopardize the whole family by bringing dishonor upon its male members or by threatening the very social fabric of their community. With such social gender ideologies prevailing, writers are aware that there can be no true liberation of women if women's bodies continue to be the only tools that carry the 'honor' of the whole family. They are also aware that if the body continues to be a subject that cannot be breached and the object upon which social and cultural behaviours are fashioned, nothing will change.

By bringing the female body centre stage, women's writing in Jordan depicts a painful femaleness that comes to surface not from being a woman but by showing that the body that defines women's identity and should be the ground for their understanding of themselves and for their sexual liberation, has become the very tool that chokes and represses them. Rather than regress to a silent and empty space, writers use images of the body and imagination to evoke a creative vision of a different dimension. The body becomes a politics of resistance as it points at an embarrassment in the conscious fabric of the social and historical Arab culture that needs to be overcome.

Female sexuality isn't seen as something to be celebrated in the short stories selected. It is a sign in the family that the woman can bring shame and dishonor to family members if she appears attractive or feminine in front of strangers. Sexual repression is the result of a rigid social and cultural heritage that continues to feed the outer image of both sexes and the inner perception of themselves. Monique Wittig in One is Not Born a Woman says: 
Sex is taken as an 'immediate given,' 'a sensible given,' 'physical features,' belonging to a natural order. But what we believe to be a physical and direct perception is only a sophisticated and mythic construction, an 'imaginary formation,' which reinterprets physical features (in themselves as neutral as others but marked by a social system), through the network of relationships in which they are perceived (48).

All the texts chosen, focus on the relationship between sexuality, culture and power in an attempt to show up that 'imaginary formation'. What is seen as the 'natural order' of male/female interaction in society is exposed by showing that it only serves the interests of one sex and leaves the female, who is considered the 'Other' and the subordinate sex, completely submerged in political absence. Women are presented as the Other of the masculine subject, according to Lacan's definition of language. Lacan says that language founds the position of the two subjects. The grammatical importance of the Other springs from the importance of keeping that 'Other' silent. Thus the speaking subject does not 'speak only to the other, it speaks of the other as an object' (Lacan 1993:38). Women become the Other of whom the lingual and phallic construction of society requires her existence to be an opacity, a negative and an Other who 'does not count as she is lost to memory at the level of la langue' (Ragland-Sullivan 1991:50). In the two short stories by Samiha Khreis and Leila Elatrash, A Case and An Ordinary Day respectively, the two female protagonists are depicted in the early stages of their lives. The period chosen is one in which the female body is starting to be conscious of itself and each protagonist is confronted by a situation where she has to consciously face her own sexuality in a social construct that does not allow room for exploration. This moment takes one of two turns: either it becomes a moment of sexual initiation giving the female pleasure by discovering her own sexuality and reaching orgasm, or else a moment in which the actual physical and psychological repression starts.

In Leila Elatrash`s short story An Ordinary Day, a group of girls go out to play in their secret place, a hidden cave. The eldest Safia is a tomboy who acts like a man carrying a stick 'as her father does to strike the ground with in order to alert his wife or her female guests that he's approaching'. As Safia's character is described, social and cultural habits are exposed. The image of her mother and father isn't an attractive one; in fact it is a traditional image based on the male/female patriarchal relationship and is one that has no inner appeal to Safia's rebellious character. It is no surprise that Safia chooses to identify herself with the symbol of power and authority in the family, her father, and she imitates him as he strikes the ground and orders the women into obedience. Safia's character unfolds once compared with the rest of the group. In playing 'she carried out her authority over the others for she only accepted being "the man" during playing and she never gave up the role'. The act of playing exposes gender roles in society as a mere play, it is a game which the short story makes fun of and ultimately uncovers the hypocrisy behind it. 
Safia turns out to be conscious of her body and the freedom it denies her. Her need to play a man is part of her desire to uncover her legs and this way come to feel that she is free and uninhibited. She likes to wear shorts but is forbidden to do so because her father 'screamed and objected because the girl has grown up and shouldn't be exposing her legs.' Furthermore, he 'cursed the women who imitate men'. Her father has clear-cut divisions of gender allowances and gender roles. To trespass either border means a threat to the identity he deems sacred and a toying with the social foundation that preserves his very role as head of the family. Safia realizes that it is only by carrying out the role of a man that she wins back her identity and is able to tuck her dress in her underwear in order to regain authority over her own body.

The short story is written in no satirical tone to indicate a sense of rejection and rebellion on behalf of the writer but there is no doubt about Elatrash's intention. She writes knowing that her readers' consciousness will automatically add up the assimilated image of the inequality between the two sexes and feel the necessity of changing social values and attitudes towards women. Her intention is fully uncovered as a stranger falls inside the cave where the girls are playing. Since Safia used the masculine voice of authority, the girls turn to her expecting the same protection they get from a man. The mental image the young girls have of themselves shows their helplessness and weakness in society as they have to bow down to masculine power knowing it is the only power that can provide them with protection. What is interesting is that the mother is never thought of as having the power to protect. The maternal role is kept within the boundaries of the domestic sphere and in this short story it amounts to very little in practical life.

In the girls' eyes, Safia is a man and they expect her to act from an authoritative and powerful point of view. But soon the masculine role she assumes becomes no more than a child's simple playing the minute she looks into the stranger's eyes and sees 'something ... she had never seen in her father's eyes'. It is at this point that she experiences her first moment of sexual consciousness. The stranger places his hand on her bare thigh and 'A stinging shiver ran through her body that was bound by the chains of fear'. The moment of being initiated into womanhood is one that will remain crystallized as a moment of fear in Safia's consciousness and is one that will map out future expectations of herself as a woman in such a society. When the stranger asks what role she is playing, she stutters and answers in a barely audible voice: 'I ... I... the father ... the man'. Her language shows that she has lost her position as an independent subject able to proudly and confidently utter ' $\mathrm{I}$ ', like men, and at this point she loses her political right of verbal representation as she succumbs to her expected role as the female Other. The stranger's comment enhances her feelings of shame for being a woman who has taken the underserved role of a man as he says: 'A man ... ha, ha ... and he has such thighs?' Safia is made to suffer the shame and guilt of her body and discovers that she has lost her voice and authority because of her beauty that she learns must remain hidden and never to be exposed in public. He realizes that she can no longer be what Lacan calls a speaking subject but has to be the Other who is 
spoken 'to' and spoken 'of' (Lacan 1993:38). The stranger soon asks her 'But do you know what men do?' and his question conjures up a world of men in front of her full of secrets and mysteries and her feelings become mixed with fear and shame of having stepped out of her place as a woman. After this incident, Safia no longer pretends to be a man and plays on equal terms with the rest of the girls as she is ousted from power and political representation due to the body she carries. The stranger lets them go when he finds out who Safia's father is and it is this recognition of man to man in a world of men that frees the girls from his grip.

The short story ends as the girls flee away and silently take their places beside the elder women in the community and beside their mothers with Safia amongst them. The story is clear in meaning and the way the writer intends the text to be interpreted. The act of reading has become a role that is no longer devoid of political implications. The reader has to be in quest of the 'correct' reading realizing that modern texts do not offer a definite meaning. Elatrash's text is true to the nature of Jordanian society in its representation as the story is built on the 'receiver' community which differs from the view of the community from which the story originated (Chen 1992:486). The receiver community or readers are expected to see through the falsehood and injustice done to women who haven't even got the right over their own bodies. The act of understanding is one of chastisement as it includes a self-understanding or a re-understanding by evaluating social mores. This is the message that Elatrash and others intend to deliver.

Samiha Khreis moves to another area of female body consciousness as she focuses on the psychological repression of women in A Case. Khreis starts with the physical and moves to psychological depths as she depicts a female patient who narrates the story saying 'I usually overcome most of my pains for I am not the kind of person who finds sickness pleasant or succumbs to it'. We have a protagonist who rejects any form of bodily dis - ease. In a sense, she is a woman who trained herself to be divorced from her body. She trained herself to overcome any kind of pain but she confesses that this time it was out of her control as she says, 'I realized I needed treatment'. There is a realization that help will not come from inside but is one sought from the community. She seeks the aid of a male doctor who assures her that she is too young to have a heart attack though she appears to suffer from its symptoms. To be certain that she is fine, they decide to carry out a scan. As she waits her turn the nurse whispers in her ear assuring: 'Women don't need a heart specialist, it is only men who die of a heart attack and between you and me they deserve it'. At this point, the case no longer becomes that of our protagonist but rather the heartache becomes a symptom that all women suffer from.

The story unfolds as the patient lies down in bed and starts conjuring faces from the past. Having put her hand on the condition she is suffering from 'men', the protagonist soon recollects her life from childhood. The first image that strikes her mind is that of a foal when she was but seven years old. She recollects how she attended its birth and watched it grow under her care into 'a beautiful, strong and golden horse'. She describes the foal saying 'he was 
unruly and could skillfully escape being caught but my father tamed him when he became older'. She unconsciously identifies with the foal and feels tamed by the father-figure as she grew up. The young girl liked the foal's free nature as when she rode him she felt like a 'princess'. The whole experience is summed up when her father loosens his grip on the horse and stands behind to watch her ride on her own. At that moment the horse 'shook its beautiful head and started chasing the wind'. The young girl cries out in fear and they soon surround the horse from all directions and catch her before she falls down. As she calms down, she confesses: 'but a cunning feeling kept coming back to me: how tasty, astonishing and wonderful this trip of fear was'. This is the one experience in which she had herself exposed to the unknown away from her father's protection and taming attitude. It is this feeling that springs back to her as she lies in hospital waiting for the result of the scan. She says:

I see him approach but I do not utter a word. He yielded completely for a couple of minutes just like he did in my childhood; then he rushed far away from the sight of those present. Heedless of the doctor's sensors and the covers he slipped in my veins. Feeling the warmth of my blood he burst like fire and rushed from one vein to another. I choked the cries of childhood so he penetrated me and when his star shone at the door of my heart I opened my eyes.

The doctor looks at the heart diagram and sees a horse. At this moment she says 'I relaxed in bed and that cunning childhood feeling came back to me: frightful, tasty, astonishing and wonderful'. The implications are those of a sexual orgasm that she had never experienced since her childhood and had learnt to repress. The horse diagram is her defiance against her father's sheltered and safe upbringing and the doctor's equipment that tries to conform to social codes and ascribed scientific behavior. The story tackles psychological aspects of repressive conditions relating the sexual with the political. The image of the horse in the diagram is her way of manifesting her defiance to the outside world and she succeeds in confusing the doctor who says 'Strange! What's this? A horse ... Repeat the scan ... I am not sure'. Khreis is rejecting the repressive upbringing women are subjugated to and shatters the certitude of science when dealing with a female heart and body. The use of science here alludes to the fact that women's sexuality has not been fully uncovered and explored and the most intrinsic feelings of a woman's sexual orgasm remains repressed. The doctor's rejection of the evidence is an allusion to the fact that society still rejects women's sexuality and refuses to bring it out in the open even in a medical clinic. Like Elatrash, the story targets the reader's intelligence and the message is one that challenges a whole set of social mores and standards showing that it is about time that women are allowed to explore their own sexuality without any inhibitions.

Later generations of female writers in Jordan, give a more obtrusive account of their own dissatisfaction with social norms and bodily gender inscriptions. The story line or plot does not take the centre stage as it does with 
the writers of the first generation of the 1970's. The second generation resorts to the usage of bolder statements when it comes to women's bodies. For example, Samia Atout's stories are brief and depict a psychological state or an impression more than a development of plot. Under the heading Paintings she subtitles a story called $A$ Naked Painting that reads:

I was as naked as the day I was born; I ripened, and opened up.

When we met he scribbled with his brush on my body. He spread his colours on my minutest folds and bent over them, licking them and showing me a glowing space.

I clung onto my short dress and pulled it down to cover up my knees as I listened in astonishment to the details of his crazy dream!

The woman is reflected as man's jouissance where she has no say and no control not only over her actions but even over her own body. She becomes a spectator of her own physical growth and is then covered up by the colours of a man who silences her into his own world without any chance of a separate representation of her own self. The feminist aspect is more apparent in Atout's work as she speaks straight to her readers without hiding behind a story line. The portrait is indicative of a cause that needs to be resolved and of a social disease that must be cured. Shoshana Felman (1981:25) in Rereading Femininity says:

Defined by man, the conventional polarity of masculine and feminine names woman as a metaphor of man. Sexuality ... functions ... as the sign of a rhetorical convention, of which woman is the signifier and man the signified. Man alone has thus the privilege of proper meaning.

When Atout says 'I listened in astonishment to the details of his crazy dream' she has rendered his lingual power useless by describing it as insane. She has floored the 'privilege of his proper meaning' as she rejects the space where he wants to corner her into so that he can assert his own identity. The power play comes very much to surface as he spreads his colours on her body, on her minutest details; that is, she becomes a reflection of his own desires and fantasies, she becomes his jouissance. The image of her body and the language of his words do not add up to the scribbling of his brush on her body. What this short story is saying is that woman's body has never been left naked but has always been shaped and reshaped by the man's crazy dream of being the sole possessor of the phallus. It is the subjugation of the female body to that of the male surveyor and owner.

Another example can be seen in Jawaher Rafaiaa's short story The Dress. The story once again is about a young girl whose childhood innocence is massacred in one act. It depicts the transition from childhood to adulthood as outlined by dressing up in terms of hiding the body that reveals the girl's sexuality. The story starts with the girl's own stream of consciousness showing 
a free soul running around joyous and carefree. She imagines herself a flower, a butterfly and a gazelle leaping freely in nature when all of a sudden she says: 'just as I was about to let out a laugh to a horizon flooded with light, my childish laugh is stifled by a masculine voice, my father's! Why on earth is he calling out to me with such severity!' She does not wonder for long as she obediently rushes back home passing her hunchbacked grandmother sitting at the doorstep in the sun and she feels sorry for her 'miserable appearance'. She also passes her mother and two sisters who are washing piles of dirty clothes. Women's lot does not seem to amount to a great deal in her eyes but the protagonist is too young to associate herself with any of them. She finds her father and her 'rough brothers' gathered waiting for her. The father beckons to her brothers who bring something wrapped up. Then her father moves towards her:

He looks at my small body and says: 'It's about time!'

I shake in confusion mixed with the alarm bell of feminine fear that turns in seconds into childish mirth. Maybe it's a present being the youngest in the house. I feel comfortable with the thought so I close my eyes and smile.

She soon unwraps her present to discover that it is a long black dress and a white scarf. Her mother starts dressing her up in her new costume with 'sympathetic fingers'. She says: 'I feel terribly sad and cry in outrage. It's the dress I love the most. My helpless mother sadly whispers in my ear: "You've grown up!" Her father then orders her to go inside and stay with the rest of the women in the house. Her mother with lowered eyes guides her inside: 'In the narrow room where I sat amid my two sisters I felt my back and the tip of my fingers stumble across a small hump from which a wild plant had just sprouted.' The story ends without much ado but the final lines show a wild plant sprouting in her body. Like the rest of the writers, Rafaiaa is targeting her readers' consciousness as she points out that the story cannot forever continue to end there. Liberating the female body must take place as the corner they are pushed into is no longer acceptable.

Lizbet Goodman (1996) says that the text affords a space to forward 'a politics and cognition of the historical and cultural subordination of women ... and a resolve to do something about it' (x). Writers present a collective experience of injustice and of sexual subordination and repression. Their stories add up to help reinforce an essential female experience that cannot be hushed up any more. The act of writing is very important as women's fiction endorses the female story by presenting female lives. This is a conscious act of changing things. It is what Jeanette Winterson (1996:60) in Art Objects says is a conscious attempt to make a difference, to change society: 'If we can fictionalize ourselves, and consciously, we are freed into a new kind of communication'.

The act of writing is therapeutic as sharing the hurt and sharing stories is part of ridding oneself of the burden of carrying it alone. It is also a vital 
element in self-growth and in surpassing boundaries. Leila Elatrash (2005) in her article Women and Writing says that the act of writing allowed her to cross boundaries; to surpass taboos and to breach many worlds she was forbidden. She confesses:

I found in writing the courage that the immobilized granddaughters of Scheherazade failed to attain with their clipped wings. I wanted to jump from the high fences that outlined their lives according to what is allowed and what is prohibited. The more I grew up, the more words carried for me new interpretations of things and of remarks my mother used to obstruct or to mysteriously, hastily and quickly pass them in a manner that meant that a young girl like me should not know them. The early lines at school taught me some given truths from which questions sprang which I circled with longing and persistence but my mother and teachers used to put an end to my trials of finding out and questioning with a whip of taboos.

\section{Conclusion}

The writings of Leila Elatrash and other female writers in Jordan are directed to sweep the mass consciousness of a society into action in order to transcend current norms and values, held part of the social web. They all clearly state that it is then, not before, that a new story can be written. The act of writing the body includes an act of reading it and by reading it a true understanding and a vision of liberation can then begin.

Note: All short stories used are translated from the Arabic by Dr. Omnia Amin and have been published in The Jordan Times Weekender as listed in the works cited below.

\section{References}

Amin, Omnia (2003). "Atout Sketches the Naked Shadow of Being." The Jordan Times Weekender, 11April, vol. 28, No. 8335.

Amin, Omnia (2004). "Elatrash Shattering Fetters." The Jordan Times Weekender, 16 \&24 April, vol. 29, No. 8643 \& 8649.

Amin, Omnia (2002). "Khreis and the Struggle to Combine." The Jordan Times Weekender, 12 July, vol. 27, No. 8107.

Amin, Omnia (2002). "Rafaiaa Crying Out Loud." The Jordan Times Weekender, 26 July, vol. 27, No. 8119.

Chen, Xiaomei (1992). "The Poetics of Misunderstanding: A Historical Model of Cross-Cultural Literary History." Canadian Review of Comparative Literature. December, 485-506.

Csordas, Thomas J (1990). "Embodiment as a Paradigm for Anthropology.” Ethos. 18.

Elatrash, Leila (2005). Women and Writing, Cultural Week of the Faculty of Arts Philadelphia University in Jordan, 12 Jan. 
Felman, Shoshana (1981). "Rereading Femininity.” Yale French Studies, 62, 28.

Goodman, Lizbeth, ed. (1996) Approaching Literature: Literature and Gender. London: The Open University.

Lacan, Jacques (1993). Trans. Russell Grigg. The Psychoses: The Seminar of Jacques Lacan Book III 1955-1956. Ed. Jacques-Alain Miller. London: Routledge.

Ragland-Sullivan, Ellie, ed. (1991). "The Sexual Masquerade: A Lacanian Theory of Sexual Difference." Lacan and the Subject of Language. New York: Routledge, 49-82.

Winterson, Jeanette (1996). Art Objects: Essays on Ecstasy and Effrontery. U.K.: Vintage.

Wittig, Monique (1981). "One is Not Born a Woman”, Feminist Issues, vol. 1, No. 2, Winter. 